\title{
Production and Nutritive Value of Aspen Understory, Black Hills
}

\section{KIETH E. SEVERSON}

\section{Abstract}

Production of and nutrient concentrations in understory vegetation was measured in aspen stands representing three different seral stages in the Black Hills. There was little variation in concentrations of nutritive elements in the same plant species among stands. Differences in species composition and shrub, forb, grass, and total production caused some variation in total available nutrients. Production of aspen understory, while variable (676$1226 \mathrm{~kg} / \mathrm{ha}$ ), was one of the higher producing types in the area. Digestible dry matter, fiber, lignin, and calcium were at acceptable levels for white-tailed deer growth. Protein and phosphorus concentrations may be considered marginal, but variation in concentrations among plant species, the large number of plant species available, and the selective feeding habits of deer may preclude nutrient deficiencies in their diet. The value each of the seral stages has to livestock and wildlife is discussed and management suggested.

Quaking aspen (Populus tremuloides) stands have been recognized as important to many wildlife species and to livestock because of the diversity they create in otherwise homogeneous conifer stands and for the variety and productivity of understory vegetation (Reynolds 1969, Kranz and Linder 1973). Understory production has been studied in several areas of the West, including Utah (Ellison and Houston 1958, Cook and Harris 1968), Colorado (Paulsen 1969), Arizona (Reynolds 1969), South Dakota (Kranz and Linder 1973), and Wyoming (Bartos and Mueggler 1981). Selected nutritive characteristics have also been reported by Cook and Harris (1968) and Paulsen (1969).

Aspen, however, generally is considered a seral stage that will gradually be replaced by conifers (Jones 1974) with few exceptions (Severson and Thilenius 1976, Mueggler 1976). Studies thus far have not related the seral stage of aspen to understory productivity or nutritive content. This study examines these parameters in aspen stands that represented different successional stages.

\section{Study Area}

The study was conducted in the Black Hills of western South Dakota and northeastern Wyoming. Specific study sites were selected from aspen groups as defined and described by Severson and Thilenius (1976), who separated aspen stands of the Black Hills into 9 homogeneous groups by cluster analysis of a similarity matrix based on physical site, soil, and vegetation characteristics. Three groups that contained the largest number of stands and also represented different seral stages were selected for production and nutrient analysis. Group 1 was comprised of 8 stands, and was characterized by a very high average density of small diameter $(<10.2 \mathrm{~cm}$ d.b.h.) aspen stems. Average age was 28 years. Most sites in group 1 had burned 31 to 39 years ago. The successional

\footnotetext{
The author is research wildlife biologist, Rocky Mountain Forest and Range Experiment Station, Arizona State University, Tempe, Arizona, 85287. Headquarters is in Fort Collins, in cooperation with Colorado State University.

Research reported here was conducted while author was stationed with Rocky

Mountain Forest and Range Experiment Station, Rapid City, South Dakota.

The aut hor thanks Arthur V. Carter, Jeremiah J. Kranz, and Lyle E. Petersen of the South Dakota Department of Game, Fish and Parks for their cooperation and assistance with deer collections.

Manuscript received June 29, 1981.
}

status (seral versus relatively stable) of stands in this group could not be determined because they were too young. This group will be called the young group.

Aspen group 3 contained 7 stands made up of larger trees $(10.2-20.3 \mathrm{~cm}$ d.b.h.) as well as the smaller size class $(<10.2 \mathrm{~cm}$ d.b.h.) at about one-fifth the density of stands in the young group. Average stand age was 61 years. Most sites had burned 60 to 80 years ago. Ponderosa pine (Pinus ponderosa) and white spruce (Picea glauca) were invading in significant amounts which indicated significant progress towards an eventual conifer climax. This group will be called the mid-age group.

Aspen group 5 supported stem densities intermediate to the previous groups, with about one-half as many trees in the 10.2-20.3 $\mathrm{cm}$ d.b.h. class as in the smaller size class. Most stands were young, 15 to 19 years old. This group also differed from the others in that it had a herbaceous understory dominated by rhizomatous or stoloniferous species. The lush nature of the understory and close proximity to water encouraged use by cattle. The sod and presence of cattle combined to suppress both conifer reproduction and aspen suckering, thus complicating the normal successional process (Severson and Thilenius 1976). This group will be called the altered group.

\section{Methods}

Two aspen stands were randomly selected from each of the three described groups. Two $38 \times 38 \mathrm{~m}$ macroplots were randomly established within each stand and fenced to prevent grazing by cattle. White-tailed deer (Odocoileus virginionus) occasionally grazed the plots, but use was insignificant. A $30.5 \times 30.5 \mathrm{~m}$ area within the macroplot was sampled, leaving a buffer strip $3.75 \mathrm{~m}$ wide around the periphery.

Production of current annual growth of the woody and herbaceous understory was measured at its peak in late July to early August of 1972 and 1973 using a double-sampling technique called the dry weight prediction method (Blair 1959). Green weights were estimated by species on 60 randomly selected, $30.5 \times 60.9 \mathrm{~cm}$ plots in each macroplot. Vegetation on 12 of these plots, also randomly selected, was clipped, oven-dried, and weighed. A linear regression quantified the relationship of oven-dried weight $(Y)$ to estimated green weight $(\mathbf{X})$.

The composite shrub, forb, and grass categories used for nutrient analyses reflected their proportional presence in the understory. Samples included material from each species in the same proportion that they occurred in the total production of that class. The four individual species analyzed, three shrubs and one forb; common snowberry (Symphoricarpos albus), shinyleaf spirea (Spiraea lucida), Wood's rose (Rosa woodsii), and cream peavine (Lathyrus ochroleucus) - are important summer foods for whitetailed deer (Schneeweis et al. 1972) and were found in all plots.

All samples were analyzed for digestible dry matter using the 2-stage in vitro technique (Tilley and Terry 1963) with inocula from 12 adult white-tailed deer that were collected on summer range that had extensive aspen stands. Crude protein, ash, calcium, and phosphorus were determined by standard laboratory procedures (Association of Official Agricultural Chemists 1965). Acid detergent fiber and acid detergent lignin were determined through procedures developed by Van Soest (1963).

Stands within each group were categorized by cluster analysis using vegetation characters as partial criteria (Severson and Thilenius 1973). Therefore, the groups are already known to be different and statistical analysis based on randomization is inappropriate. 
Table 1. Understory production of selected species and vegetation classes in three aspen groups, Black Hills, South Dakota and Wyoming, 1972 and 1973. Expressed as kg/hatstandard deviation, oven-dried weight.

\begin{tabular}{|c|c|c|c|c|c|c|c|c|c|}
\hline \multirow[b]{2}{*}{ Year } & \multirow[b]{2}{*}{ Aspen group } & \multicolumn{7}{|c|}{ Species/forage class } & \multirow[b]{2}{*}{ Total } \\
\hline & & Snowberry & Spirea & Wood's rose & Peavine & Other shrubs ${ }^{\prime}$ & Other forbs ${ }^{2}$ & Grasses & \\
\hline 1972 & $\begin{array}{l}\text { Young } \\
\text { Mid-aged } \\
\text { Altered }\end{array}$ & $\begin{array}{l}38 \pm 10 \\
23 \pm 13 \\
36 \pm 10\end{array}$ & $\begin{array}{r}27 \pm 19 \\
43 \pm 13 \\
6 \pm 6\end{array}$ & $\begin{array}{r}47 \pm 28 \\
7 \pm 5 \\
22 \pm 11\end{array}$ & $\begin{array}{l}28 \pm 19 \\
24 \pm 14 \\
14 \pm 14\end{array}$ & $\begin{array}{r}402 \pm 96 \\
182 \pm 102 \\
71 \pm 32\end{array}$ & $\begin{array}{l}174 \pm 47 \\
261 \pm 59 \\
431 \pm 59\end{array}$ & $\begin{array}{l}172 \pm 71 \\
136 \pm 29 \\
646 \pm 115\end{array}$ & $\begin{array}{r}887 \pm 77 \\
676 \pm 81 \\
1,226 \pm 125\end{array}$ \\
\hline 1973 & $\begin{array}{l}\text { Young } \\
\text { Mid-aged } \\
\text { Altered }\end{array}$ & $\begin{array}{l}32 \pm 7 \\
19 \pm 11 \\
27 \pm 10\end{array}$ & $\begin{array}{r}28 \pm 11 \\
43 \pm 13 \\
4 \pm 3\end{array}$ & $\begin{array}{l}39 \pm 28 \\
10 \pm 6 \\
20 \pm 10\end{array}$ & $\begin{array}{l}17 \pm 15 \\
21 \pm 6 \\
15 \pm 15\end{array}$ & $\begin{array}{r}406 \pm 56 \\
231 \pm 211 \\
49 \pm 21\end{array}$ & $\begin{array}{l}101 \pm 11 \\
235 \pm 72 \\
326 \pm 44\end{array}$ & $\begin{array}{l}176 \pm 39 \\
179 \pm 27 \\
489 \pm 81\end{array}$ & $\begin{array}{l}800 \pm 76 \\
738 \pm 160 \\
931 \pm 57\end{array}$ \\
\hline
\end{tabular}

'Excluding snowberry, spirea, and Wood's rose.

${ }^{2}$ Excluding peavine.

Several within-group comparisons of nutrient concentrations were made using analysis of variance because selection of stands, macroplots, and production plots was random. No consistent differences were noted among or between most attributes, so only means and standard deviations were tabulated.

\section{Forage Production}

\section{Results and Discussion}

Relative production of forage classes within and between groups remained consistent over both years, but differences were less pronounced the second year (Table 1). Shrubs produced the most forage in the young group; shrubs and forbs shared dominance in the mid-age group; grasses and forbs were primary producers in the altered group, with grasses predominating. Shrub dominance in the young group was caused in part by the presence of snowbush ceanothus (Ceanothus velutinus). Although shrubs and forbs produced most forage in mid-age stands, no single species contributed over $30 \%$ of the total amount in either category over both years. Roughleaf ricegrass (Oryzopsis asperfolia), however, produced $60 \%$ and $65 \%$ of the total grass weight over the 2 respective years. Kentucky bluegrass (Poa pratensis) and white clover (Trifolium repens) accounted for about one-half of the total grass and forb production, respectively, in the altered group.

Production of the selected species important to deer (Table 1) was quite uniform across all groups with only two notable exceptions. Shinyleaf spirea was an insignificant part of the understory in the altered group, and Wood's rose produced little annual growth in the mid-age group even though it was present in all stands (Severson and Thilenius 1976). Total production of these four species was greatest in the young and lowest in the mid-age group in both years.

Forage production in unmanaged aspen stands compares favorably with data from other Black Hills vegetation types. Only the moist meadows dominated by Kentucky bluegrass produced more, 730 to $2,850 \mathrm{~kg} / \mathrm{ha}^{1}$ (Pase and Thilenius 1968); this exceeded the 676 to $1,226 \mathrm{~kg} / \mathrm{ha}$ reported in Table 1 . More xeric meadow types produced from 634 to $1,608 \mathrm{~kg} / \mathrm{ha}^{\mathrm{l}}$ (Pase and Thilenius 1968), and heavily thinned immature or sapling $(8$ to $10 \mathrm{~cm}$ average d.b.h.) ponderosa pine stands produced from $1,311 \mathrm{~kg} / \mathrm{ha}$ (Severson and Boldt 1977) to $1,520 \mathrm{~kg} / \mathrm{ha}^{1}$ (Pase 1958). The dry meadows and lightly stocked, immature pine stands produced forage in quantities comparable to aspen stands. However, more mature, polesized (about 15 to $18 \mathrm{~cm}$ average d.b.h.) pine stands produced much less forage, regardless of pine stocking levels, as did more heavily stocked sapling stands (Pase 1958, Severson and Boldt 1977).

Understory production in aspen stands does not appear to be controlled by or related to any aspen overstory parameters. Many studies have documented inverse relationships between various overstory characteristics, such as canopy cover, density, and basal area, and understory production in hardwood and softwood stands (Ffolliott and Clary 1972). Such relationships are not evident in stands in which aspen is the sole dominant (Harper 1973,

\footnotetext{
Indicates production on an air-dried rather than oven-dried basis.
}

Severson and Kranz 1976). Aspen has the capability of producing large, extensive lateral root systems which can influence understory production (Ellison and Houston 1958). Severson and Kranz (1976) have suggested that the influence of root systems, which may vary in extent and development depending on the number of disturbances to which the stand had been subjected, could mask any effects of the aspen overstory. As conifers invade, however, understory production will decline (Harper 1973). These declines have been significantly related to basal area of the invading conifer and the total basal area, aspen plus conifer (Severson and $\mathrm{Kranz}$ 1976). This does not imply that thinning a pu re aspen stand will not result in increased production, only that the response will not necessarily be related to overstory parameters. Thinning aspen will result in increased understory, especially grasses, forbs, and aspen sprouts (Reynolds 1969).

Understory production in aspen stands is apparently related to the age of the stand-not necessarily chronological age, but seral stage as measured by degree of conifer invasion. Data in Table 1 indicate chronological age might be influential in this respect, but successional rates vary on different aspen sites (Bartos 1973) so aspen stands of different ages could have similar quantities of conifers present. The close association between understory production and coniferous overstory parameters indicate that degree of conifer invasion would be a more reliable indicator of understory potential.

\section{Nutritive Content}

There were no significant differences $(P<0.05)$ in any nutritive elements between the 2 years, so these data were pooled in Tables 2 and 3. No consistent variations were noted among groups for any nutritive parameter. Most differences within groups were consistent and expected. Forbs were generally more digestible than shrubs, which in turn were significantly more digestible than grasses $(P<0.05)$. White-tailed deer, the inocula source, fed almost exclusively on forbs and shrubs during summer (Schneeweis et al. 1972). The lower digestibility of grasses may be a reflection of the adaptability of rumen microorganisms to this diet. Digestibility of shrubs, forbs, and the four selected species ranged between $50 \%$ to $60 \%$. This, according to Urness (1973), was excellent for deer.

Forbs contained slightly higher crude protein levels (Table 2), which was partly due to the influence of leguminous species such as cream peavine (Table 3) and clover. Cream peavine was an important protein source for white-tailed deer which required a diet containing $13 \%$ to $20 \%$ for optimum growth and development (Ullrey et al. 1967). Using Urness' (1973) standards, all composited samples (Table 2) and the other selected species contained only fair protein levels.

Acid detergent fiber levels were significantly higher $(P<0.05)$ in grasses than in forbs or shrubs in all groups. Shrubs contained significantly more acid detergent lignin $(P<0.05)$. Although no single criteria has been developed to predict digestibility of a ruminant forage item, there is a general, inverse relationship between fiber and lignin content and digestibility. When judged by criteria developed by Urness (1973) fiber contents of common snowberry and Wood's rose were excellent, all others were good except grasses, which rated fair. 
Table 2. Nutritive concentrations in composited forage classes, aspen understory, Black Hills, South Dakota and Wyoming. Expressed as percent \pm standard deviation of oven-dried weight.

\begin{tabular}{|c|c|c|c|c|}
\hline \multirow{2}{*}{$\begin{array}{l}\text { Nutritive } \\
\text { element }\end{array}$} & \multirow[b]{2}{*}{ Forage class } & \multicolumn{3}{|c|}{ Aspen group } \\
\hline & & Young & Mid-aged & Altered \\
\hline $\mathrm{DDM}^{1}$ & $\begin{array}{l}\text { Shrubs } \\
\text { Forbs } \\
\text { Grasses }\end{array}$ & $\begin{array}{l}54.1 \pm 3.7 \\
59.0 \pm 9.4 \\
41.1 \pm 5.3\end{array}$ & $\begin{array}{l}49.2 \pm 3.6 \\
54.1 \pm 3.6 \\
38.8 \pm 3.4\end{array}$ & $\begin{array}{l}55.8 \pm 6.6 \\
62.8 \pm 5.0 \\
42.8 \pm 5.2\end{array}$ \\
\hline Protein & $\begin{array}{l}\text { Shrubs } \\
\text { Forbs } \\
\text { Grasses }\end{array}$ & $\begin{array}{l}8.3 \pm 0.4 \\
9.1 \pm 1.1 \\
6.4 \pm 0.8\end{array}$ & $\begin{array}{l}8.2 \pm 0.7 \\
8.3 \pm 0.6 \\
7.5 \pm 0.4\end{array}$ & $\begin{array}{r}7.5 \pm 0.3 \\
10.0 \pm 1.4 \\
6.1 \pm 0.5\end{array}$ \\
\hline $\mathrm{ADF}^{2}$ & $\begin{array}{l}\text { Shrubs } \\
\text { Forbs } \\
\text { Grasses }\end{array}$ & $\begin{array}{l}29.1 \pm 2.3 \\
34.0 \pm 2.2 \\
43.8 \pm 3.5\end{array}$ & $\begin{array}{l}34.0 \pm 3.0 \\
38.1 \pm 3.2 \\
44.6 \pm 1.9\end{array}$ & $\begin{array}{l}31.5 \pm 2.2 \\
31.5 \pm 2.8 \\
42.3 \pm 2.4\end{array}$ \\
\hline $\mathrm{ADL}^{3}$ & $\begin{array}{l}\text { Shrubs } \\
\text { Forbs } \\
\text { Grasses }\end{array}$ & $\begin{array}{r}10.1 \pm 1.7 \\
7.0 \pm 1.1 \\
5.3 \pm 0.5\end{array}$ & $\begin{array}{r}12.2 \pm 1.2 \\
9.7 \pm 0.3 \\
6.0 \pm 0.6\end{array}$ & $\begin{array}{r}10.0 \pm 1.3 \\
6.2 \pm 1.0 \\
5.1 \pm 0.6\end{array}$ \\
\hline Ash & $\begin{array}{l}\text { Shrubs } \\
\text { Forbs } \\
\text { Grasses }\end{array}$ & $\begin{array}{l}6.7 \pm 0.7 \\
9.3 \pm 0.7 \\
8.7 \pm 0.9\end{array}$ & $\begin{array}{l}5.8 \pm 0.5 \\
9.0 \pm 0.9 \\
9.9 \pm 1.3\end{array}$ & $\begin{array}{r}5.9 \pm 0.4 \\
10.1 \pm 1.2 \\
9.5 \pm 1.2\end{array}$ \\
\hline Calcium & $\begin{array}{l}\text { Shrubs } \\
\text { Forbs } \\
\text { Grasses }\end{array}$ & $\begin{array}{l}1.31 \pm 0.19 \\
1.62 \pm 0.15 \\
0.49 \pm 0.11\end{array}$ & $\begin{array}{l}1.09 \pm 0.18 \\
1.38 \pm 0.18 \\
0.41 \pm 0.07\end{array}$ & $\begin{array}{l}0.92 \pm 0.10 \\
1.54 \pm 0.23 \\
0.51 \pm 0.08\end{array}$ \\
\hline Phosphorus & $\begin{array}{l}\text { Shrubs } \\
\text { Forbs } \\
\text { Grasses }\end{array}$ & $\begin{array}{l}0.29 \pm 0.02 \\
0.22 \pm 0.03 \\
0.20 \pm 0.02\end{array}$ & $\begin{array}{l}0.25 \pm 0.03 \\
0.25 \pm 0.03 \\
0.19 \pm 0.02\end{array}$ & $\begin{array}{l}0.27 \pm 0.04 \\
0.20 \pm 0.02 \\
0.16 \pm 0.02\end{array}$ \\
\hline
\end{tabular}

${ }^{1} \mathrm{DDM}=$ Digestible dry matter.

${ }^{2} \mathrm{ADF}=$ Acid detergent fiber

${ }^{3} \mathrm{ADL}=$ Acid detergent lignin

Ash is a general measure of total mineral content, but its value in nutrition may be obscured by the presence of quantities of inert material, such as silica (Dietz 1972). Shrubs contained significantly less $(P<0.05)$ ash than forbs or grasses. Calcium and phosphorus are two minerals generally reported on an individual basis in forage analyses because both are needed in relatively large quantities (Dietz 1972). In sampled aspen stands (Table 2) forbs had higher calcium concentrations than shrubs; grasses contained the lowest percentages. Phosphorus concentrations were more uniform, but highest percentages were found in shrubs and the lowest in grasses.

There was more variation in calcium concentrations of individual species (Table 3). Cream peavine and Wood's rose in most instances contained a significantly higher $(P<0.05)$ concentration of calcium than common snowberry or shinyleaf spirea. Phosphorus percentages were uniform among the three shrubs, but cream peavine had about one-half as much.

Forage classes and individual species all contained levels of calcium that exceeded optimum requirements for white-tailed deer (Ullrey et al. 1973). Phosphorus contents were lower than required in forbs and grasses (Table 2). Selective feeding habits of deer could increase phosphorus intake to an acceptable level because shrubs in general (Table 2) and the 3 important shrub species in their diet (Table 3) contained more phosphorus than the $0.26 \%$ recommended for optimum growth by Ullrey et al. (1975).

Calcium:phosphorus ratios are an equally important consideration because excessive calcium can interfere with phosphorus metabolism. A desirable ratio lies somewhere between $1: 2$ to $2: 1$, although wider ratios are acceptable if ample Vitamin $D$ is present (Dietz 1972). Ca:P ratios of grasses (2:1) were optimum according to Urness' (1973) criteria. Shrubs as a group and the three shrub species had $\mathrm{Ca}: \mathrm{P}$ ratios that ranged from $3: 1$ to $4: 1$, considered good to fair. Forbs (5:1 to 7:1) and cream peavine (10:1 to $11: 1)$ had ratios that Urness (1973) classified as poor.

Only limited data are available on nutritive values of forage produced in other Black Hills vegetation types. Dietz (1972) reported digestible dry matter, protein, acid detergent fiber, acid detergent lignin, cellulose, ash, calcium, phosphorus, and gross
Table 3. Nutritive concentrations in four selected species from aspen understory, Black Hilk, South Dakota and Wyoming. Expressed as percent \pm standard deviation oven-dried weight.

\begin{tabular}{|c|c|c|c|c|}
\hline \multirow{2}{*}{$\begin{array}{l}\text { Nutritive } \\
\text { element }\end{array}$} & \multirow[b]{2}{*}{ Species } & \multicolumn{3}{|c|}{ Aspen groups } \\
\hline & & Young & Mid-aged & Altered \\
\hline \multirow{4}{*}{$\mathrm{DDM}^{\prime}$} & Snowberry & $57.0 \pm 4.8$ & $54.0 \pm 4.5$ & $57.4 \pm 7.6$ \\
\hline & Spirea & $50.4 \pm 5.0$ & $46.4 \pm 5.4$ & $52.4 \pm 5.0$ \\
\hline & Rose & $52.8 \pm 4.2$ & $53.4 \pm 5.7$ & $57.2 \pm 6.9$ \\
\hline & Peavine & $52.6 \pm 3.2$ & $50.6 \pm 4.4$ & $54.9 \pm 6.0$ \\
\hline \multirow{4}{*}{ Protein } & Snowberry & $7.5 \pm 0.6$ & $7.8 \pm 0.4$ & $8.0 \pm 1.5$ \\
\hline & Spirea & $6.5 \pm 0.4$ & $6.9 \pm 0.5$ & $7.3 \pm 0.8$ \\
\hline & Rose & $7.5 \pm 0.5$ & $8.0 \pm 0.8$ & $8.2 \pm 0.3$ \\
\hline & Peavine & $15.5 \pm 1.4$ & $17.0 \pm 1.4$ & $16.7 \pm 1.0$ \\
\hline \multirow{4}{*}{$\mathrm{ADF}^{2}$} & Snowberry & $28.2 \pm 2.6$ & $28.8 \pm 1.3$ & $26.6 \pm 1.5$ \\
\hline & Spirea & $33.1 \pm 2.4$ & $32.8 \pm 2.1$ & $32.9 \pm 2.1$ \\
\hline & Rose & $25.8 \pm 1.8$ & $25.4 \pm 2.1$ & $24.2 \pm 1.1$ \\
\hline & Peavine & $34.6 \pm 3.3$ & $34.3 \pm 1.3$ & $32.9 \pm 1.7$ \\
\hline \multirow{4}{*}{$\mathrm{ADL}^{3}$} & Snowberry & $9.1 \pm 0.8$ & $9.5 \pm 0.9$ & $9.5 \pm 1.4$ \\
\hline & Spirea & $11.0 \pm 1.1$ & $10.6 \pm 1.0$ & $10.0 \pm 1.0$ \\
\hline & Rose & $7.1 \pm 0.9$ & $6.3 \pm 1.0$ & $6.5 \pm 0.7$ \\
\hline & Peavine & $8.6 \pm 1.6$ & $8.2 \pm 1.3$ & $7.1 \pm 0.7$ \\
\hline \multirow{4}{*}{ Ash } & Snowberry & $8.2 \pm 0.1$ & $7.7 \pm 0.5$ & $7.5 \pm 0.5$ \\
\hline & Spirea & $6.0 \pm 0.5$ & $6.1 \pm 0.6$ & $6.2 \pm 0.7$ \\
\hline & Rose & $7.3 \pm 0.5$ & $7.3 \pm 0.6$ & $7.0 \pm 0.4$ \\
\hline & Peavine & $8.1 \pm 0.9$ & $8.9 \pm 0.6$ & $8.2 \pm 0.6$ \\
\hline \multirow{4}{*}{ Calcium } & Snowberry & $1.23 \pm 0.05$ & $1.24 \pm 0.15$ & $1.15 \pm 0.11$ \\
\hline & Spirea & $1.10 \pm 0.18$ & $1.04 \pm 0.20$ & $1.04 \pm 0.11$ \\
\hline & Rose & $1.51 \pm 0.10$ & $1.55 \pm 0.10$ & $1.39 \pm 0.14$ \\
\hline & Peavine & $1.75 \pm 0.31$ & $1.92 \pm 0.21$ & $1.78 \pm 0.14$ \\
\hline \multirow{4}{*}{ Phosphorus } & Snowberry & $0.38 \pm 0.05$ & $0.30 \pm 0.03$ & $0.34 \pm 0.08$ \\
\hline & Spirea & $0.35 \pm 0.08$ & $0.33 \pm 0.04$ & $0.29 \pm 0.05$ \\
\hline & Rose & $0.38 \pm 0.05$ & $0.37 \pm 0.03$ & $0.34 \pm 0.04$ \\
\hline & Peavine & $0.18 \pm 0.02$ & $0.18 \pm 0.02$ & $0.18 \pm 0.01$ \\
\hline
\end{tabular}

'DDM = Digestible dry matter.

${ }^{2} \wedge \mathrm{DF}=$ Acid detergent fiber.

${ }^{3} \mathrm{ADL}=$ Acid detergent lignin

energy contents of seven browse species during each season of the year. Two species, Wood's rose and common snowberry, had summer nutritive values similar to those in Table 3 . These were the only species common to both studies.

Variation existing in relative proportions of available nutrients among aspen groups (Table 2) is a function of species composition of each class. The relative proportions of each species varied among groups (Severson and Thilenius 1976). Overlapping confidence intervals between groups for the individual species that were tested (Table 3) indicate similarities in nutritive content. This implies that variations in sites, soils, or successional stage do not result in corresponding differences in the nutrient content of a species.

Regardless of nutrient percentage, there will be differences in total amount of that nutrient in an aspen group because of unequal forage production. The altered group, for example, produced greater quantities of most nutrients due to greater forage production, although amounts varied proportionally because of differences in production of each forage class within and between years (Table 4). Relatively less lignin was produced in the altered group because of the low lignin content of grasses as compa red to sh rubs. The nearly equal proportions of calcium and phosphorus among all groups was also a function of annual production and nutrient percentage of forage classes.

\section{Conclusions and Recommendations}

The productive and diverse nature of aspen understory indicates a useful resource for both livestock and many wildlife species. Aspen stands, generally, are dynamic seral stages that will gradually be replaced by conifers, ponderosa pine or white spruce, in the Black Hills (Severson and Thilenius 1976). Aspen stand manage- 
Table 4. Maximum ranges of nutrient production, including variations in forage production and nutrient percentages within and between years. Expressed as kg/ha, oven-dried weight.

\begin{tabular}{lccc}
\hline \hline & \multicolumn{3}{c}{ Aspen group } \\
\cline { 2 - 4 } Nutritive element & Young & Mid-aged & Altered \\
\hline Digestible dry matter & $296-553$ & $226-438$ & $346-849$ \\
Protein & $45.3-87.8$ & $38.6-71.1$ & $49.4-119.1$ \\
Acid detergent fiber & $182-350$ & $176-310$ & $168-587$ \\
Acid detergent lignin & $46.2-90.3$ & $45.6-91.8$ & $33.7-97.2$ \\
Calcium & $6.08-13.92$ & $4.81-9.67$ & $5.47-14.40$ \\
Phosphorus & $1.24-2.79$ & $1.11-2.10$ & $1.20-2.99$ \\
\hline
\end{tabular}

ment is confounded because all stages can be important to specific uses. Cattle, for example, tend to use aspen stands that are relatively free of conifers and have a high proportion of grass in the understory (Kranz and Linder 1973), a description that fits the altered group of this study. During summer white-tailed deer, however, prefer a type similar to the mid-age group, or what $\mathrm{K}$ ranz and Linder (1973) described as a mixed aspen-pine type. Ruffed grouse (Bonasa umbellus) apparently require very dense, small aspen growth without conifers like the young group, for brood habitat, and older age classes similar to the altered group for winter habitat (Gullion and Svoboda 1972).

Although the nutritive values of species in aspen understory do not appear to differ from those produced in other vegetation types, higher total production results in greater nutrient production per hectare. Aspen understory, like other vegetation types in the western United States, may have some nutrient limitations as related to utilization by ruminants, particularly of protein and phosphorus (or calcium:phosphorus ratios). These limitations can be overcome by selective feeding habits of animals. White-tailed deer, for example, selected plants higher in protein (cream peavine) and higher in phosphorus (common snowberry, shinyleaf spirea, and Wood's rose) than that which was available in the understory as a whole. Management can create the opportunity for grazing a nimals to utilize this selectivity by insuring that quantity and quality of understory vegetation are balanced. Aspen understory is valuable in this respect because, in addition to being relatively productive, it reportedly contains more species than either mixed aspen-pine or pure pine in the Black Hills (Kranz and Linder 1973). There are equally important differences within the aspen complex; the young aspen group produced the greatest amount (116 to $140 \mathrm{~kg} / \mathrm{ha}$ ) of the four forage species white-tailed deer utilize, the mid-age group an intermediate a mount ( 93 to $97 \mathrm{~kg} / \mathrm{ha}$ ), while the altered group produced the least ( 66 to $78 \mathrm{~kg} / \mathrm{ha}$ ).

The aspen complex cannot be managed with a single objective or by a single treatment. A variety of seral aspen stages should be created, where it does not already exist, to maximize quantity and quality of the forage and to realize the diversity that is apparently necessary for all uses of this type. Managers can encourage such diversity in large, homogeneous aspen stands by using one or several of these suggested treatments: (1) clearcutting to promote aspen regeneration to create a mosaic of age classes, (2) thinning aspen to promote understory growth, (3) removing invading conifers to promote growth of understory and to slow succession, (4) removing most aspen but retaining all conifers to speed succession, and (5) thinning aspen and conifers to increase understory growth and wood fiber production.

\section{Literature Cited}

Association of Official Agricultural Chemists. 1965. Official methods of analysis, 10th ed. Association of Official Agricultural Chemists. 957 p.

Bartos, D.L. 1973. A dynamic model of aspen succession. p. 11-26. In: International Union of Forestry Research Organizations. Biomass study. 532 p. Univ. Maine Press, Orono.

Bartos, D.L., and W.F. Mueggler. 1981. Early succession in aspen communities following fire in western Wyoming. J. Range Manage. 34:315318.

Blair, Robert M. 1959. Weight techniques for sampling browse production on deer ranges. p. 26-31. In: Proceedings of a symposium: Techniques and methods of measuring understory vegetation. [October 27-31, 1958;
Tifton, Georgia]. USDA FS., Southern Forest Exp. Sta. and Southeastern Forest Exp. Sta. 174 p.

Cook, C. Wayne, and Lorin E. Harris. 1968. Nutritive value of seasonal ranges. Agr. Exp. Sta. Bull. 472.55 p. Utah State Univ., Logan.

Dietz, Donald R. 1972. Nutritive value of shrubs. p. 289-302. In: Cyrus M. McKell, James P. Blaisdell, and Joe R. Good in, technical editors. Wildland shrubs-thcir biology and utilization-An international symposium [July 1971; Logan, Utah]. USDA FS. Gen. Tech. Rep., INT-1. 494 p. Intermt. Forest and Range Exp. Sta., Ogden, Utah.

Elison, Lincoln, and Walter R. Houston. 1958. Production of herbaceous vegetation in openings and under canopies of western aspen. Ecology 39:337-345.

Ffolliott, Peter F., and Warren P. Clary. 1972. A selected and annotated bibliography of understory-overstory vegetation relationships. Agr. Exp. Sta. Tech. Bull. 198. 33 p. Univ. Ariz., Tucson.

Gullion, Gordon W., and Franklin J. Svoboda. 1972. The basic habitat resource for ruffed grouse. p. 113-119. In Aspen Symposium Proceedings. USDA FS. Gen. Tech. Rep. NC-1. 154 p. North Central Forest Exp. Sta., St. Paul, Minn.

Jones, John R. 1974. Silviculture of southwestern mixcd conifers and aspen: The status of our knowledge. USDA FS Res. Pap. RM-122.44 p. Rocky Mt. Forest and Range Exp. Sta., Fort Collins, Colo.

Harper, K.T. 1973. The influence of tree overstory on understory production and composition in aspen forests of central Utah. p. 22. In: Abstracts of papers-26th Annual Meeting of the Soc. Range Manage. [February 1973; Boise, Id.]. 31 p.

Kranz, Jeremiah J., and Raymond L. Linder. 1973. Value of Black Hills forest communities to deer and cattle. J. Range Manage, 26:263-265.

Mueggler, W.F. 1976. Type variability and succession in Rocky Mountain aspen. p. 16-19. In: Utilization and marketing as tools for aspen management in the Rocky Mountains. Proceedings of the Symposium [September 8-9, 1976, Fort Collins, Colo.]. USDA FS Gen. Tech. Rep. RM-29, 120 p. Rocky Mt. Forest and Range Exp. Sta., Fort Collins, Colo.

Pase, Charles P. 1958. Herbage production and composition under immature ponderosa pine stands in the Black Hills. J. Range Manage. 11:238243.

Pase, Charles P., and John F. Thilenius. 1968. Composition, production, and site factors of some grasslands in the Black Hills of South Dakota. USDA FS Res. Note RM-103. 8 p. Rocky Mt. Forest and Range Exp. Sta., Fort Collins, Colo.

Paulsen, Harold A., Jr. 1969. Forage values on a mountain grassland-aspen range in western Colorado. J. Range Manage. 22:102-107.

Reynolds, Hudson G. 1969. Aspen grove use by deer, elk, and cattle in southwestern coniferous forests. USDA FS Res. Note RM-138. 4 p. Rocky Mt. Forest and Range Exp. Sta., Fort Collins, Colo.

Schneeweis, James C., Kieth E. Severson, and Lyle F. Petersen. 1972. Food habits of deer in the Black Hills. Part 1: Northern Black Hills. Agr. Exp. Sta. Bull. 606. 35 p. South Dakota State Univ., Brookings, S.D.

Severson, Kieth E., and Charles E. Boldt. 1977. Options for Black Hills forest owners: Timber, forage, or both. Rangeman's J. 4:13-15.

Severson, Kieth E., and Jeremiah J. Kranz. 1976. Understory production not predictable from aspen basal area or density. USDA FS Res. Note RM-314. 4 p. Rocky Mt. Forest and Range Exp. Sta., Fort Collins, Colo.

Severson, Kieth E., and John F. Thilenius. 1976. Classification of qua king aspen stands in the Black Hills and Bear Lodge Mountains. USDA FS Res. Pap. RM-166. 24 p. Kocky Mt. Forest and Range Exp. Sta., Fort Collins, Colo.

Tilley, J.M.A., and R.A. Terry. 1963. A two-stage tech nique for the in vitro digestion of forage crops. J. British Grasslands Soc. 18:104-111.

Ullrey, D.E., and W.G. Youatt, H.E. Johnson, A.B. Cowan, L.D. Fay, R.L. Covert, W.T. Magee, and K.K. Keahey. 1975. Phosphorus requirements of weaned white-tailed deer fawns. J. Wildlife Manage. 39:590595.

Ullrey, D.E., W.G. Youatt, H.E. Johnson, L.D. Fay, and B.L. Bradley. 1967. Protein requirement of white-tailed deer fawns. J. Wildlife Manage. 31:679-685.

Ullrey, D.E., W.G. Youatt, H.E. Johnson, L.D. Fay, B.L.Schoepke, W.T. Magee, and K.K. Keahey. 1973. Calcium requirements of weaned whitetailed deer fawns. J. Wildlife Manage. 37:187-194.

Urness, Philip J. 1973. Deer nutrition in Arizona chaparral. Part II. Chemical analyses and in vitro digestibility of seasonal deer forages. Special Rep. No. 3. 68 p. Ariz. Game and Fish Dep., Phoenix, and USDA FS, Rocky Mt. Forest and Range Exp. Sta., Fort Collins, Colo.

Van Soest, P.J. 1963. Use of detergents in the analysis of fiberous feeds. 11. A rapid method for the determination of fiber and lignin. J. Assoc. Official Agricultural Chemists 46:829-835. 